\title{
Eight decades of evolution in public health from the perspective of the Institute of Epidemiological Diagnosis and Reference
}

\author{
José Alberto Díaz-Quiñonez* \\ Instituto de Diagnóstico y Referencia Epidemiológicos "Dr. Manuel Martínez Báez", Secretaría de Salud, Ciudad de México, Mexico
}

To become aware of our history is to become aware of our singularity. It is a moment of reflective repose before we devote ourselves to action again.

Octavio PAZ ${ }^{1}$

The Sanitary and Tropical Diseases Institute (ISET - Instituto de Salubridad y Enfermedades Tropicales) started operating in early $1938^{*, 2}$ and was formally opened on March 18, 1939, in commemoration of the first anniversary of the oil expropriation. ${ }^{3}$ At ISET, scientific studies were conducted to address epidemics and endemics caused by tropical or exotic pathologies, or those grouped in the so-called "colonial medicine". During five decades, ISET integrated a large number of interdisciplinary health research teams, contributed to the professionalization of prominent generations of Mexican sanitarians and obtained well-deserved international prestige.

With this solid and prestigious tradition, on the $50^{\text {th }}$ anniversary of its opening, ISET became the National Institute of Epidemiological Diagnosis and Reference "Dr. Manuel Martínez Báez". This new stage, of just over a decade, was characterized by the contribution of the Institute for national seroepidemiological surveys ${ }^{4}$ and by a huge promotion of research. ${ }^{5,6}$ The promulgation of the Law of National Health Institutes during the first democratic transition in the year 2000, which aimed to regulate their organization and operation, promote research, teaching and the provision of services, formalized the Institute's subsequent evolution.?

* Ramírez-Hernández JA, Guzmán-Bracho C, Díaz-Quiñonez JA. Desde el ISET al InDRE. I. Instituto de Salubridad y Enfermedades Tropicales: Génesis y primeros años, 1934-1940. DOI: 10.24875/GMM.19005157. Gac Med Mex. 2019;155:322-327.
Over the past 20 years, changes have been dramatic. The world was transformed in the face of the threat of international terrorism in September 2001, and the concept of biological risk acquired another meaning for public health laboratories. The national epidemiological surveillance system incorporated bioterrorism surveillance and the Institute implemented confirmatory diagnostic procedures for anthrax and other emerging diseases. ${ }^{8}$ Efforts were undertaken to implement an institutional quality assurance system in view of the ineluctable participation in newly formed regional and global networks. The establishment of the Global Health Security Initiative allowed the participation of the Institute in forums and discussions of the highest level. During the influenza pandemic in 2009 , a diagnostic algorithm and a network of laboratories for influenza molecular confirmation were established throughout the country. ${ }^{9}$ The crisis generated by this public health emergency allowed the authorization of resources to build new and modern strategic facilities. The relocation of valuable biological materials, including historical collections of infectious substances, constituted a national special security event in terms of biological risk management. ${ }^{10}$

In eight decades of contributions to public health, the Institute has leaned on the work of its human capital. Throughout its history, the Institute has brought together (among executives, professionals and technical personnel) recognized public health experts, a permanent delegate of the United Nations Educational, Scientific and Cultural Organization and founder of the National College (for reference: http://colnal.mx), delegates participating in the constitution of the World Health Organization, a National Science Award winner, two undersecretaries of the
Correspondence:

*José Alberto Díaz-Quiñonez

E-mail: alberto.diaz@salud.gob.mx
Date of reception: 14-03-2019

Date of acceptance: 21-03-2019

DOI: 10.24875/GMM.M19000261
Gac Med Mex. 2019;155:204-205

Contents available at PubMed www.gacetamedicademexico.com 
branch and a large number of scientists who are members of the National System of Researchers, of the Mexican Academy of Science, as well as secretaries and presidents of the National Academy of Medicine of Mexico, all of them exponents not only of science and technology, but of humanist spirit. All this accounts for the training, the commitment, the size and the human talent the Institute has offered to public health.

In this context of leadership consolidation, on the $80^{\text {th }}$ anniversary of its foundation, the Institute continues its evolution. The proposal to create the National System for Health Diagnosis, dependent on the nascent Sub-secretariat of Public Health, ${ }^{11}$ will require the attributions, experience and tradition of the institution that, until today, has been the Institute of Epidemiological Diagnosis and Reference "Dr. Manuel Martínez Báez". For this transformation, the motive, the time, the place, the person, the means and the form will have to be considered. If all this is properly reflected and weighted, our country awaits success in terms of public health policy, with a fortified Institute and a firm vision into the future.

\section{References}

1. Paz O. El laberinto de la soledad, posdata y vuelta al laberinto de la soledad. México: Fondo de Cultura Económica; 2015.

2. Oficina Sanitaria Panamericana. Instituto Mexicano de Investigación. Bol Oficina Sanit Panam. 1938;269.

3. Martínez-Báez M. El Instituto de Salubridad y Enfermedades Tropicales. An Soc Mex Hist Ciencia y Tecnol. 1969;1:143-162.

4. Sepúlveda-Amor J. Editorial. Salud Publica México,1992;34:119-120.

5. Valdespino-Gómez JL, García-García ML, Del Río-Solezzi A, et al. El Instituto Nacional de Diagnóstico y Referencia Epidemiológicos "Dr. Manuel Martínez Báez" En: Una institución académica y dieciséis investigadores distinguidos. Quincuagésimo quinto aniversario del INDRE. México: Secretaría de Salud; 1994. p. 189-197.

6. Flisser-Steinbruch A, Velasco-Villa A, Martínez-Campos C, et al. Infectious diseases in Mexico. A survey from 1995-2000. Arch Med Res. 2002;33:343-350.

7. Flisser-Steinbruch A. Editorial. Salud Publica Mex. 2000;42:482-483.

8. Sarti E, Moreno-Galván M, Rodríguez-Angeles G, et al. Molecular characterization of anthrax in positive powders: a Mexican experience. J Clin Microbiol. 2003;41:4909.

9. Díaz-Quiñonez JA, Alpuche-Aranda CM. Métodos diagnósticos de influenza por laboratorio. En: Córdova-Villalobos, Valdespino-Gómez, Ponce-de-León. La epidemia de influenza A/H1N1 en México. México: Médica Panamericana; 2010. p. 87-105.

10. Ochoa-Carrera LA. Traslado de materiales biológicos valiosos a las nuevas instalaciones del Laboratorio Nacional de Referencia de México, Instituto de Diagnóstico y Referencia Epidemiológicos (InDRE). Tesis de Maestría en Gestión de la Salud, Universidad del Valle de México, Campus Lomas Verdes, 2014

11. Academia Nacional de Medicina. La salud en la cuarta transformación de México. Sesión conjunta entre la Secretaría de Salud y la Academia Nacional de Medicina de México. Disponible en: https://m.youtube.com watch?v=Qp1JqOIHXGU\# 